Disclosure of Interest: E. AlemaoShareholder of: Bristol-Myers Squibb, Employee of: Bristol-Myers Squibb, L.Ferri Employee of: Bristol-Myers Squibb, D. Paul Employee of: Bristol-Myers Squibb, A. Marshall Share holder of: BristolMyers Squibb, Employee of:Bristol-Myers Squibb, L. McDonald Employee of: Bristol-Myers Squibb, A. Rao Consultant for: Bristol-Myers Squibb, V. Anupindi Consultant for: Mu Sigma, G.Craig Share holder of: Discus Analytics, Grant/ research support from: Bristol-Myers Squibb, Consultant for: Premera Blue Cross/ Blue Shield of Washington and Alaska, Celgene, Bristol-Myers Squibb, Genentech, Novartis, Employee of: Arthritis Northwest, Paid instructor for: Washington State University Elson Floyd School of Medicine; University of Washington, Speakers bureau: Bristol-Myers Squibb, UCB, Genentech, Celgene, Novartis, Abbvie,Sanofi/Regeneron, Eli Lily, K. Knapp Shareholder of: Discus Analytics, LLC, Employee of: Discus Analytics, LLC

DOI: 10.1136/annrheumdis-2018-eular.2582

\section{SAT0134 MORTALITY AND MULTIPLE CAUSES OF DEATH IN RHEUMATOIDARTHRITIS PATIENTS. RESULTS FROM A LARGE POPULATION-BASED COHORT IN THE VENETOREGION, 2010-2015.}

F. Ometto ${ }^{1}$, U. Fedeli ${ }^{2}$, C. Botsios ${ }^{3}$, E. Schievano ${ }^{2}$, M. C. Corti ${ }^{2}$, L. Punzi ${ }^{1}$ ${ }^{1}$ Department of Medicine - DIMED, Univeristy of Padova; ${ }^{2}$ Epidemiological Department, Veneto Region; ${ }^{3}$ Department of Medicine - DIMED, University of Padova, Padova, Italy

Background: Mortality rates in patients with rheumatoid arthritis (RA) are 1.5-1.6 fold higher than in the general population ${ }^{1,2}$. No recent data on mortality in large cohorts of RA patients in Italy are available.

Objectives: The aim of this study was to assess standardized mortality ratios (SMRs) and multiple causes of death in RA subjects living in the Veneto Region between 2010 and 2015

Methods: We identified in the electronic archive of the Veneto Region a cohort of patients aged 20-89 years who were exempt from copayment for RA in January 2010, and linked them with the archive of causes of deaths of the period 20102015. The record-linkage was performed on previously anonymized records. In the Veneto Region a copy of all death certificates is transmitted to the Regional Epidemiology Service for coding of causes of death according to the International Classification of Diseases, 10 th Edition. Each subject was followed from 1st January 2010 either until death, or 90 years of age, or 31st December 2015, whichever came first.

In the Veneto Region, the archive of causes of death include all diseases mentioned in the death certificate, and the selection of the underlying cause of death (UCOD) is performed by means of the Automated Classification of Medical Entities, a computer program developed by the US National Center for Health Statistics. SMRs with $95 \%$ confidence intervals, were computed as the ratios between deaths observed in the cohort, and those expected according to age- and genderspecific regional mortality rates.

\begin{tabular}{lcc}
\hline $\begin{array}{l}\text { Number of deaths and standardized mortality ratio (SMR) } \\
\text { Interval (Cl) }\end{array}$ & with 95\% Confidence \\
\hline & Deaths (n) & SMR (95\% CI) \\
\hline Certain infectious and parasitic diseases (A00-B99) & 88 & $2.34(1.88-2.89)$ \\
Septicemia (A40-A41) & 66 & $3.07(2.37-3.90)$ \\
Neoplasms (COO-D48) & 519 & $0.98(0.90-1.07)$ \\
Diseases of the blood and blood-forming organs (D50-D89) & 23 & $3.22(2.04-4.83)$ \\
Endocrine, nutritional and metabolic diseases (E00-E90) & 57 & $0.96(0.73-1.25)$ \\
Diabetes mellitus (E10-E14) & 43 & $0.93(0.67-1.26)$ \\
Mental and behavioural disorders (F00-F99) & 50 & $0.90(0.67-1.18)$ \\
Dementia (F00-F03) & 44 & $0.86(0.62-1.15)$ \\
Diseases of the nervous system (G00-G99) & 61 & $0.89(0.68-1.14)$ \\
Alzheimer's disease (G30) & 27 & $0.90(0.59-1.31)$ \\
Diseases of the circulatory system (I00-199) & 783 & $1.56(1.45-1.67)$ \\
Hypertensive diseases (I10-I15) & 101 & $1.51(1.23-1.83)$ \\
Ischemic heart diseases (I20-I25) & 247 & $1.51(1.33-1.71)$ \\
Other heart diseases (I00-I09, I26-I51) & 201 & $1.64(1.42-1.88)$ \\
Cerebrovascular diseases (I60-I69) & 182 & $1.43(1.23-1.65)$ \\
Diseases of the respiratory system (J00-J99) & 177 & $1.83(1.57-2.12)$ \\
Pneumonia (J12-J18) & 61 & $2.22(1.70-2.86)$ \\
Chronic lower respiratory diseases (J40-J47) & 54 & $1.47(1.10-1.92)$ \\
Interstitial pulmonary diseases (J84) & 20 & $3.47(2.12-5.36)$ \\
Diseases of the digestive system (K00-K93) & 117 & $1.93(1.60-2.32)$ \\
Vascular disorders of intestine (K55) & 21 & $2.40(1.48-3.66)$ \\
Diseases of liver (K70-K76) & 20 & $0.95(0.58-1.47)$ \\
Diseases of the musculoskeletal system (M00-M99) & 149 & $17.3(14.7-20.4)$ \\
Rheumatoid arthritis (M05-M06) & 130 & $63.3(52.9-75.2)$ \\
Diseases of the genitourinary system (N00-N95) & 27 & $1.29(0.85-1.88)$ \\
External causes of mortality (V01-Y84) & 70 & $1.65(1.28-2.08)$ \\
Falls (W00-W19) & 20 & $1.95(1.19-3.01)$ \\
All causes & 2142 & $1.42(1.36-1.48)$ \\
\hline
\end{tabular}

Results: Overall 16,098 residents diagnosed with RA and aged 20-89 years were enrolled in the cohort. Follow-up was complete for above $99 \%$ of study subjects. The overall follow-up amounted to 88,599 person-years, with 2,142 registered decedents. The most common causes of death were circulatory diseases $(36.6 \%)$, neoplasms $(24.2 \%)$,and respiratory diseases (8.3\%). SMR in RA subjects was 1.42 (1.36-1.48).Mortality was significantly increased from circulatory, respiratory, digestive, infectious, hematological diseases and falls (figure 1). Mortality fromneoplasms was similar to that expected based on rates from the generalpopulation. RA was selected as the underlying cause of death in $6.1 \%$ of all deaths in the cohort and was mentioned in $25.4 \%$ of death certificates.

Conclusions: Overall, a $42 \%$ excess risk of death could be observed among patients with RA in the Veneto Region. These data confirm results from previous studies in large cohorts of RAsubjects [1,2].

\section{REFERENCES}

[1] Sokka T, Abelson B, Pincus T. Mortality in rheumatoid arthritis: 2008 update. Clin Exp Rheumatol 2008;26(Suppl 51):S35-61.

[2] van den Hoek J, Boshuize HC, Roorda LD, et al. Mortality in patients with rheumatoid arthritis: a 15-year prospective cohort study. Rheumatol Int 2017;37:487-493.

Disclosure of Interest: None declared

DOI: 10.1136/annrheumdis-2018-eular.4307

\begin{tabular}{|l|l}
\hline SAT0135 & CYTOKINE ACTIVATION AND FORMATION OF \\
NEPHROPATHY IN EARLY RHEUMATOID ARTHRITIS: \\
CLINICAL AND PATHOPHYSIOLOGICAL PARALLELS
\end{tabular}

D. Rekalov ${ }^{1}$, G. Prytkova ${ }^{1}$, R. Kulynych ${ }^{1} .{ }^{1}$ Rheumatology, Zaporizhzhia Regional Clinicalhospital, Zaporizhzhia, Ukraine

Background: RA is characterized by not only joints destruction, but also of other organs and systems, particularly, lungs, heart, blood vessels, kidneys, etc. Nephropathy is currently the leading symptomatic complex of Rheumatoid Arthritis (RA), with upto $73 \%$ frequency, being identified as a prognostic criterion of diseaseseverity and outcome. The development of renal insufficiency, as a rule, is the main cause of the fatal outcome of RA without possibility of regular hemodialysis to such patients.

Objectives: of the study are to determine pathophysiological relation between cell-mediated immunity (tumornecrosis factor-alpha (TNF- $\alpha$ )) activation and renal dysfunction in the patients with early RA (eRA).

Methods: We analyzed the datafrom 35 early RA patients of average age of $50,71 \pm 2,25$ years (ranged 18 - 76years, $80 \%$ of women) with $9,21 \pm 0,43$ months mean duration of the disease by the time of the study initiation. Urine and blood tests were performed to verify the main indicators of kidney function and inflammation cytokines significant interaction.

Results: All signs of renaldys function at the baseline in the patients with eRA were associated with glomerular filtration rate decrease and excretion of urine protein increase. Dynamics of albumin urine, according to the analysis of variance for one-factorscheme, were significantly determined by the state of disease activity, reflecting the severity of joint damage. High urine $\beta$-2-microglobulin level wassignificantly associated with the expression rate of main inflammatorycytokines as per binary regression analysis.

Table 1. Differences in the renal function features in the patients with early RA depending on the TNF- $\alpha$ expression ( $\mathrm{M} \pm \mathrm{m}$ (95\%- confidence interval)).

\begin{tabular}{|c|c|c|c|c|}
\hline \multirow[b]{2}{*}{ Indicator, units of measure } & \multicolumn{3}{|c|}{ Patients with $\mathrm{RA}(\mathrm{n}=35$ ) } & \multirow{2}{*}{$\begin{array}{l}\text { The level of } \\
\text { significance of } \\
\text { differences } \\
\text { between group }\end{array}$} \\
\hline & $\begin{array}{c}\text { The TNFF- } a \text { level less } \\
\text { than the median } 170 \mathrm{pg} \\
\operatorname{ml}(\mathrm{n}=18)\end{array}$ & $\begin{array}{c}\text { The TNF-a level higher } \\
\text { than the median } 170 \mathrm{pg} / \mathrm{m} \\
(\mathrm{n}=17)\end{array}$ & $\begin{array}{l}\text { In general, for the } \\
\text { group }(n=35)\end{array}$ & \\
\hline $\begin{array}{l}\text { GFR Cockroft-Gault, } \\
\mathrm{ml} / \mathrm{min}\end{array}$ & $135,66 \pm 4,15$ & $121,58 \pm 5,55$ & $129,54 \pm 3,95$ & $p<0,05$ \\
\hline Albumin urine, $\mathrm{mg} / \mathrm{L}$ & $\begin{array}{r}70,48=15,09 \\
(40,3-100,67)\end{array}$ & $\begin{array}{c}124,27 \pm 15,02 \\
(94,22-154,31)\end{array}$ & $\begin{array}{r}70,48 \pm 15,09 \\
(40,3-100,67)\end{array}$ & $p<0,05$ \\
\hline $\begin{array}{c}\beta_{2} \text {-microglobulin urine, } \\
\mu g \mathrm{~L}\end{array}$ & $\begin{array}{c}983,28 \pm 72,39 \\
(758,5-1128,06)\end{array}$ & $\begin{array}{c}1438,53=100,21 \\
(1238,11-1638,95)\end{array}$ & $\begin{array}{c}1283,28=72,39 \\
(1138,5-1428,06)\end{array}$ & $\mathrm{p}<0,05$ \\
\hline $\begin{array}{l}\text { The ratio of albumin } / \\
\text { creatinine urine, } \mathrm{mg} / \mathrm{g} \\
\text { creatining }\end{array}$ & $\begin{array}{c}38,79 \pm 3,8 \\
(31,2-56,39)\end{array}$ & $\begin{array}{c}95,93 \pm 14,9 \\
(71,13-110,73)\end{array}$ & $\begin{array}{c}83,83 \pm 9,63 \\
(64,58-103,09)\end{array}$ & $p<0,05$ \\
\hline $\begin{array}{l}\text { Glomerular penetration index, } \\
\text { mg/ }\end{array}$ & $\begin{array}{l}0,42 \pm 0,04 \\
(0,34-0,5)\end{array}$ & $\begin{array}{l}1,23 \pm 0,24 \\
(0,74-1,72)\end{array}$ & $\begin{array}{l}0,81 \pm 0,14 \\
(0,54-1,09)\end{array}$ & $p<0,05$ \\
\hline
\end{tabular}

Conclusions: The obtained dependence showed the dynamics of expression of tubular disorders in early RA with a progressive deterioration which did associate with the levels of TNF- $\alpha$ expression, and variety of the urine microglobulin rates in the interval 200-350 $\mu \mathrm{g} / \mathrm{L}$. Reliable correlation $(r=0.51, p<0.05)$ between beta- 2 microglobulinuria and TNF- $\alpha$ levels was clearly shown, revealing the relationship described by the formula MGU $=-481+937 \times \log 10($ TNF- $\alpha)$ as per regression analysis. The severity of tubular damage in early RA is associated with TNF- $\alpha$ expression, especially in the patients with TNF- $\alpha$ above $250 \mathrm{pg} / \mathrm{mL}$, when microalbumin urine rates were significantly higher $(p=0.00043)$. We identified robust data that in the early RA patients with high TNF- $\alpha$, the number of reported cases of microalbumin urine was significantly higher than in those with low levels. 


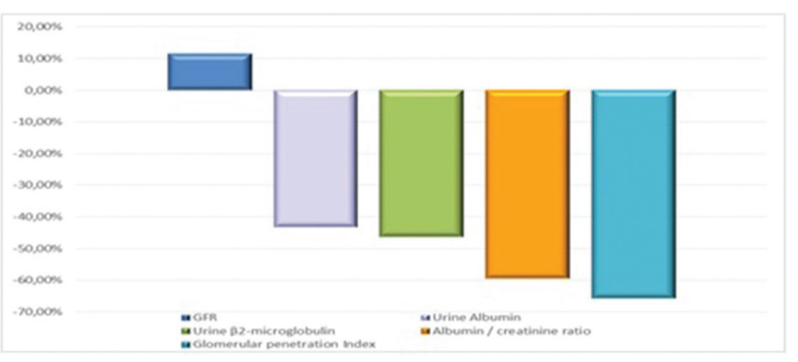

Figure 1. Differences in values of nephropathy markers in the patients with early RA, depending on TNF- $\alpha$ level.

\section{REFERENCES:}

[1] Kizaki K, Yamashita T, Hayashi et al. Infliximab is equivalently suppressingoxidative stress compared to tocilizumab among well-controlled patients withrheumatoid arthritis. Int $\mathrm{J}$ Rheum Dis 2016. doi: 10.1111/1756185X.12972

[2] Isaacs JD, Zuckerman A, Krishnaswami S, et al. Changes in serum creatinine inthe patients with active rheumatoid arthritis treated with tofacitinib: resultsfrom clinical trials. Arthritis Res Ther 2014;16(4):158. doi: 10.1186/ $\operatorname{ar4673}$

Acknowledgements: No Acknowledgements.

Disclosure of Interest: None declared

DOI: 10.1136/annrheumdis-2018-eular.1713

\section{SAT0136 THE INFLUENCE OF HDL-CHOLESTEROL AND CRP ON INCREASED INSULIN RESISTANCE AND IMPAIRED BETA-CELL FUNCTION IN PATIENTS WITH RHEUMATOIDARTHRITIS}

G. G. Ristić ${ }^{1}$, V. Subota ${ }^{2}$, D. Stanisavljević ${ }^{3}$, B. Glišić ${ }^{1}$, M. Petronijević ${ }^{1}$,

D. Stefanović ${ }^{1} .{ }^{1}$ Department of Rheumatology and Clinical Immunology; ${ }^{2}$ Institute of Medical Biochemistry, Military Medical Academy, ${ }^{3}$ Institute of Medical Statistics, Faculty of Medicine, University of Belgrade, Belgrade, Serbia

Background: Increased CRP in RApts is associated with lower levels HDL cholesterol. HDL cholesterol may enhance insulin secretion and stimulate glucose up take into skeletal muscle, adipose tissue, and liver.

Objectives: To investigate we therlow HDL, alone or in combination with CRP could explain increased insulin resistance (IR) and impaired $\beta$-cell function in RA pts in comparison to healthy controls.

Methods: The study population included 127 nondiabetic subjects (90 RA pts and 37 matched controls). We determined body mass index, waist circumference (WC), and presence of metabolic syndrome (MetS). All pts were on disease modifyingantirheumatic drugs, $65.6 \%$ on steroids (none on steroids $>10 \mathrm{mg} / \mathrm{day}$ ), and $27.8 \%$ on biologic therapy. Laboratory analyses included hsCRP, glucose, insulin, and C-peptide (as a marker of insulin secretion). Insulin resistance(IR) was calculated using the updated Homeostasis Model Assessment (HOMA2-IR), based on fasting plasma glucose and specific insulin concentrations. The output of the HOMA2 model was calibrated to give IR of 1 as normal. HOMA2-B indicates the potential of $\beta$-cells to compensate increased IR. Lack of compensatory rise of HOMA2-B implied impaired $\beta$-cell function.

Results: IR was detected in $74.4 \%$ of RA pts and in $54.2 \%$ controls, $p=0.025$. RA pts had significantly higher concentration of specific insulin, $\mathrm{C}$ peptide, and HOMA2-IR than controls, while HOMA2-B was not statistically different. Both groups were comparable regarding all other factors known to affect glucose metabolism (age, WC, presence ofMetS). We found significant differences in inflammation markers between RA pts and controls: ESR 29.5 (14-44) vs. 16.0 (10.0-20.0); hsCRP 5.5 (2.8-15) vs. 3.0(1.8-3.9); $p<0.000$ for both, as well as in lipids, especially HDL concentration $1.5 \pm 0.4$ vs $1.60 \pm 0.3, p=0.027$ and a number of the pts with low HDL ( 37.8 vs $13.5 \%, \mathrm{p}=0.007$ ). Univariant regression analysis revealed significant positive effect of $\mathrm{HDL}$ on log HOMA2-B $(\beta \quad 0.099,95 \% \mathrm{Cl}$ 0.029-0.169, $\mathrm{p}=0.006$ ) and negative, but not significant effect on HOMA2-IR. In the logistic regression, after adjustment for HDL concentration, significant differences for HOMA2-IR and insulin became less important but still persisted (Table), while significance for $\mathrm{C}$ peptide became more prominent. When we added the influence of inflammation, this favourable effect ofHDL-cholesterol on C-peptide disappeared.
Conclusions: RA pts had higher IR and impaired $\beta$-cell function in comparison to healthy controls. The augmentation of statistical significance for $\mathrm{C}$ peptide, as a marker of insulinsecretion, after adjustment for low HDL-cholesterol and significant effect of HDL on logHOMA2-B implicate its important role in disturbances of glucosemetabolism in RA.

Disclosure of Interest: None declared

DOI: 10.1136/annrheumdis-2018-eular.7479

\section{SAT0136 THE INFLUENCE OF HDL-CHOLESTEROL AND CRP ON INCREASED INSULIN RESISTANCE AND IMPAIRED BETA-CELL FUNCTION IN PATIENTS WITH RHEUMATOID ARTHRITIS}

G. G. Ristić ${ }^{1}$, V. Subota ${ }^{2}$, D. Stanisavljević ${ }^{3}$, B. Glišić ${ }^{1}$, M. Petronijević ${ }^{1}$ D. Stefanović ${ }^{1} .{ }^{1}$ Department of Rheumatology and Clinical Immunology, ${ }^{2}$ Institute of Medical Biochemistry, Military Medical Academy, ${ }^{3}$ Institute of Medical Statistics, Faculty of Medicine, University of Belgrade, Belgrade, Serbia

Background: Increased CRP in RA pts is associated with lower levels HDL cholesterol. HDL cholesterol may enhance insulin secretion and stimulate glucose uptake into skeletal muscle, adipose tissue, and liver.

Objectives: To investigate whether low HDL, alone or in combination with CRP could explain increased insulin resistance $(\mathrm{IR})$ and impaired $\beta$-cell function in RA pts in comparison to healthy controls.

Methods: The study population included 127 nondiabetic subjects (90 RA pts and 37 matched controls). We determined body mass index, waist circumference (WC), and presence of metabolic syndrome (MetS). All pts were on disease modifying antirheumatic drugs, $65.6 \%$ on steroids (none on steroids $>10 \mathrm{mg} /$ day), and $27.8 \%$ on biologic therapy. Laboratory analyses included hsCRP, glucose, insulin, and C-peptide (as a marker of insulin secretion). Insulin resistance (IR) was calculated using the updated Homeostasis Model Assessment (HOMA2-IR), based on fasting plasma glucose and specific insulin concentrations. The output of the HOMA2 model was calibrated to give IR of 1 as normal. HOMA2-B indicates the potential of $\beta$-cells to compensate increased IR. Lack of compensatory rise of HOMA2-B implied impaired $\beta$-cell function.

Results: IR was detected in $74.4 \%$ of $R A$ pts and in $54.2 \%$ controls, $p=0.025$. RA pts had significantly higher concentration of specific insulin, $C$ peptide, and HOMA2-IR than controls, while HOMA2-B was not statistically different. Both groups were comparable regarding all other factors known to affect glucose metabolism (age, WC, presence of MetS). We found significant differences in inflammation markers between RA pts and controls: ESR 29.5 (14-44) vs. 16.0 (10.0-20.0); hsCRP 5.5 (2.8-15) vs. 3.0 (1.8-3.9); $p<0.000$ for both, as well as in lipids, especially HDL concentration $1.5 \pm 0.4$ vs $1.60 \pm 0.3, p=0.027$ and a number of the pts with low HDL (37.8 vs $13.5 \%, p=0.007$ ). Univariant regression analysis revealed significant positive effect of $\mathrm{HDL}$ on logHOMA2-B $(\beta \quad 0.099,95 \% \mathrm{C}$ 0.029-0.169, $\mathrm{p}=0.006$ ) and negative, but not significant effect on HOMA2-IR. In the logistic regression, after adjustment for HDL concentration, significant differences for HOMA2-IR and insulin became less important but still persisted (Table), while significance for $\mathrm{C}$ peptide became more prominent. When we added the influence of inflammation, this favourable effect of HDL-cholesterol on C-peptide disappeared.

\begin{tabular}{|c|c|c|c|c|c|c|}
\hline $\begin{array}{l}\text { Laboratory } \\
\text { parameters }\end{array}$ & $\begin{array}{l}\text { RA pts } \\
(\mathrm{N}=90)\end{array}$ & $\begin{array}{l}\text { Controls } \\
(\mathrm{N}=37)\end{array}$ & $\mathbf{P}$ & $\begin{array}{l}\text { Adjusted } \\
\text { for HDL }\end{array}$ & $\begin{array}{l}\text { Adjusted } \\
\text { for CRP }\end{array}$ & $\begin{array}{l}\text { Adjusted for } \\
\text { HDL+CRP }\end{array}$ \\
\hline $\begin{array}{l}\text { Glucose } \\
(\mathrm{mmol} / \mathrm{l})\end{array}$ & $4.8 \pm 0.6$ & $4.7 \pm 0.8$ & ns & 1 & & \\
\hline $\begin{array}{l}\text { Insulin (pmol/ } \\
\text { L) }\end{array}$ & $\begin{array}{l}68.5 \\
(50.2- \\
102.7)\end{array}$ & $\begin{array}{l}55.3 \\
(36.0- \\
69.1)\end{array}$ & 0.008 & 0.018 & 0.048 & 0.054 \\
\hline $\begin{array}{l}\text { C peptide } \\
(\mathrm{pmol} / \mathrm{L})\end{array}$ & $\begin{array}{l}785(520- \\
1010)\end{array}$ & $\begin{array}{l}600 \\
(450-880)\end{array}$ & 0.046 & 0.025 & 0.078 & 0.066 \\
\hline HOMA2-IR & $\begin{array}{l}1.4(1.0- \\
2.3)\end{array}$ & $\begin{array}{l}1.2(0.8- \\
1.4)\end{array}$ & 0.008 & 0.019 & 0.046 & 0.053 \\
\hline HOMA2-B & $\begin{array}{l}148(116- \\
190)\end{array}$ & $\begin{array}{l}141 \\
(114-158)\end{array}$ & 0.186 & 0.136 & 0.258 & 0.165 \\
\hline HOMA2-IS & $\begin{array}{l}70(46- \\
100)\end{array}$ & $\begin{array}{l}84(71.0- \\
132)\end{array}$ & 0.010 & 0.017 & 0.074 & 0.089 \\
\hline
\end{tabular}

Conclusions: RA pts had higher IR and impaired $\beta$-cell function in comparison to healthy controls. The augmentation of statistical significance for $\mathrm{C}$ peptide, as a marker of insulin secretion, after adjustment for low HDL-cholesterol and significant effect of HDL on logHOMA2-B implicate its important role in disturbances of glucose metabolism in RA.

Disclosure of Interest: None declared

DOI: 10.1136/annrheumdis-2018-eular.7479 